\title{
Programfladestyring og organisationsforandringer i nordisk public service-fjernsyn
}

\author{
Af Henrik Søndergaard
}

Programfladestyring og strategisk programlagning er $i$ tv-konkurrencens tidsalder blevet udviklet betydeligt $i$ de nordiske public service institutioner og har medfort ikke blot programpolitiske, men også organisatoriske forandringer. I denne artikel foretages en komparativ analyse af, hvordan programfladestyring er organiseret $i \mathrm{DR}, \mathcal{N} R K$ og SVT, og en droftelse af de problemer og muligheder, som er opstået $i$ sammenhang med de organisatoriske omlagninger.

»The schedule is the locus of power in television« (John Ellis 2000)

»Public service broadcasting cannot be founded on quasi-Marxixm in the modern world «

(Michael Starks 1993)

Lige siden radioens barndom har programudbudet været udsendt som en mere eller mindre velorganiseret og under alle omstændigheder planlagt række af programmer, og allerede fra begyndelsen har dette forudsat en vis styring også af programproduktionen, ligesom de enkelte artikler i en avis altid vil blive til i en erkendelse af, at de skal indgå i et samlet redaktionelt produkt og bygger på en arbejdsdeling, som tager højde for, at den daglige avis er andet end en vilkårlig samling af artikler uden indbyrdes sammenhæng. Paddy Scannell har i sine analyser af radioens allertidligste udvikling vist, hvordan programplanlægningen grundlæggende har sit udgangspunkt i de særlige kommunikative vilkår, der gælder for radio og fjernsyn: »The basic problem of production faced by broadcasters everywhere from the start was how to devise and then maintain, a continuous, ceaseless flow of programme output (Scannell 1993: 15). I sig selv er der således intet nyt $\mathrm{i}$ at organisere programmer i de strukturerede flader, som vi kender i dag, men til gengæld har denne side af programvirksomheden takket været konkurrencen fået stadig større strategisk betydning, som efterfølgende har gjort den til et overordnet institutionelt styringsprincip.
I moderne, konkurrencebaseret fjernsyn, hvad enten det drejer sig om offentlige eller private kanaler, udgør den måde, hvorpå programfladen opbygges, styres og planlægges, det, vi her vil omtale under ét som programfladestyring, et område af den allerstørste betydning. Konkurrencen udspiller sig rigtignok i et vist omfang omkring enkelte programmer, som for et øjeblik påkalder sig særlig opmærksomhed (Big Brother, Robinson Ekspeditionen og store sportstransmissioner mv.), men i hovedsagen er styrkeforholdet mellem de forskellige tv-kanaler bestemt af programfladernes sammensætning, indhold og profil, som dagligt repeteres i faste, genkendelige mønstre. Ingen tv-kanal kan som bekendt overleve ved at sende enkelte, attraktive programmer, men er nødt til at »sælge« sig selv gennem en samlet »pakke«, som seerne er fortrolige med og i stand til at orientere sig i. Skal en tv-kanal opnå et stort og stabilt publikum, må den nødvendigvis indarbejdes $\mathrm{i}$ seernes bevidsthed som en del af, hvad man kunne kalde den »indre programplan« (Jensen et al. 1993). Som en NRKmedarbejder udtrykker det, er det nemlig »»rinne i hodet« på seeren, at konkurrencen mellom TVkanalene foregår« (Syvertsen 1997: 187). Programfladen og den markedsføring, der skabes gennem programannonceringer, henvisninger, brug af logoer og grafik, udgør substansen i den enkelte kanals mærkevareidentitet, som i sig selv er ligeså vigtig for at vinde seernes opmærksomhed, som dens strategiske betydning er afgørende i en situation, hvor kanaludbudet øges med segmentering af publikum til følge (McDowell et al. 1999). 
John Ellis peger på, hvordan programfladen ikke længere blot er det slutprodukt, der opstår som summen af programmedarbejdere og redaktørers fælles indsats, men er blevet selve udgangspunktet for programproduktionen, hvor det i følge Ellis tidligere udgjordes af de programideer, som de programproducerende dele af virksomheden frembragte. Fjernsynet var med Ellis' ord »an offer-led system«, hvor »programme-makers generated ideas for programmes and offered them to their senior management (..) The offers of ideas from programme-makers drove the whole system along« (Ellis 2000: 132). I moderne, konkurrenceorienteret fjernsyn bliver dette forhold mellem produktion og programlægning vendt på hovedet: »instead, a demand-led system has developed. Now, the senior management of television specify the kinds of programming they need to fill particular slots in their schedule. The specification is in terms of budget, genre, target audience, and likely public image. The key mechanism in this proces is the schedule« (ibid.).

Den form for programfladestyring, som John Ellis beskriver, er opstået i kommercielt tv, men har efterhånden bredt sig til public service-medierne, som presset af konkurrencen og det voksende kanaludbud har været nødt til at profilere sig stærkere og mere målrettet, end det tidligere har været nødvendigt. Programfladestyring udgør imidlertid ikke noget helt nyt fænomen, heller ikke i de nordiske lande, hvor public service-medierne længe har været under forandring, men betegner snarere en videreudvikling af nogle tendenser, som var tydelige allerede i tv-konkurrencens første år. Når det gælder public service-fjernsynet i Skandinavien, har tidligere undersøgelser vist, hvordan programfladen udvikles som et centralt konkurrenceparameter og undergår forandringer, som afspejler ændrede konkurrencevilkår og nye måder at forstå public service-opgaven på (Syvertsen 1992, Søndergaard 1994, Hellmann 1999, Edin 2000). Ikke desto mindre tyder noget på, at vi står overfor en ny fase i udviklingen, hvor »tilpasningen« til skærpede konkurrencevilkår indebærer mere gennemgribende institutionelle og organisatoriske forandringer, som til forskel fra tidligere også ændrer vilkårene for programproduktionen. Dermed berøres nogle af de angiveligt mere ømfindige områder, som ud fra gængse forestillinger har med kreativitet at gøre, og som under tiden forbindes med intet mindre end pub- lic service-mediernes »sjæl«. Ofte bliver denne udvikling betragtet blot som endnu et skridt i den »kommercialiseringsproces«, som public servicemedierne længe har været udsat for, men hidtil har ingen for alvor interesseret sig for at belyse, hvilke motiver der ligger bag, hvordan programfladestyringen virker, eller hvilke konsekvenser den egentlig har for programpolitikken og for public service-mediernes muligheder for at løse de opgaver, som de er pålagt.

I det følgende skal vi belyse, hvordan strategisk programfladestyring indføres $i$ tre af de gamle public service-institutioner, nemlig DR, NRK og SVT, med henblik på at diskutere de programpolitiske og organisatoriske konsekvenser, som disse omlægninger har forårsaget. Det, der gør studiet af disse institutioner interessant, er ikke blot, at programfladestyring så åbenlyst udgør et brud med de hidtidige måder at organisere og styre programvirksomheden på og derfor har givet anledning til ganske alvorlige interne kriser, men også at det i modsætning til, hvad der er tilfældet med de fleste kommercielle kanaler og de såkaldte hybridkanaler, drejer sig om horisontalt integrerede medieinstitutioner, hvor udsendelsesvirksomheden eksisterer side om side med produktionsvirksomheden. Da programfladestyring, som vi skal se, må betragtes som en central rammefaktor for programproduktion, og da den samtidig på den ene side er helt afgørende for, hvordan public service-kanalerne kan profilere sig på markedet, og på den anden side har stor indflydelse på, hvilke programmer der produceres og hvordan de sammensættes i sendefladen, er der god grund til at interessere sig for, hvordan denne form for styring fungerer og for dens programpolitiske konsekvenser. Den undersøgelse, hvis hovedresultater her fremlægges, bygger på et nordisk komparativt forskningsprojekt, som beskæftiger sig med sammenhængen mellem programpolitik, strategisk programlægning og organisationsforandringer ved at sammenligne udviklingen i tre af de gamle public service-institutioner ${ }^{1}$. Projektets teoretiske rammer og metodologi er beskrevet andet steds (Edin 2001, Ytreberg 2000 og 2001, Søndergaard 2001), men det kan måske alligevel være på sin plads at præcisere, at det komparative sigte snarere har drejet sig om at udvide det analytiske perspektiv, så erfaringer fra flere forskellige institutioner inddrages som et samlet empirisk materiale, end om at foretage detaljerede sammenligninger, hvor 
ligheder og forskelle trækkes frem med henblik på at vurdere, hvilke institutioner der har håndteret programfladestyringen bedst. Hvad metodologi angår, har vi baseret analysen på en kombination af dokumentanalyse, interviews og studier af konkrete programlægningsprocedurer inden for en afgrænset periode, som analyseres på baggrund af bredere organisationsmæssige og tv-æstetiske betragtninger. I den foreliggende fremstilling kan de teoretiske forudsætninger ikke fremstå som andet end skitseagtige og ufuldstændige, ligesom analysen af de institutionelle forandringer, som ofte er ganske komplekse og modsigelsesfyldte, nødvendigvis må blive alt for generel og unuanceret til at tegne et fuldstændigt billede.

\section{Programstrategier i de nordi- ske public service-institutioner}

Det ville have været nyttigt på dette sted at tegne et billede af ligheder og forskelle mellem de tre institutioner, der behandles, men pladsen tillader ikke nogen nærmere beskrivelse hverken af deres opbygning, programpolitiske profil eller generelle markedsmæssige position (jf. Bono et al. 1994). I dag opererer både DR, NRK og SVT hver to tvkanaler, som er udsat for ganske betydelig konkurrence fra især nationale hybdridkanaler ${ }^{2}$ (her tænkes på det offentligt ejede TV2 i Danmark, det privatejede TV2 i Norge og det ligeledes privatejede TV4 i Sverige), men i stigende grad også fra egentligt kommercielt fjernsyn (TV3, TvDanmark, TvNorge, Femman). Den voksende konkurrence har sammen med stadig vanskeligere økonomiske vilkår ${ }^{3}$ skabt behov for strategisk planlægning, som på sin side har forudsat nye former for programfladestyring. Ser man på de tre institutioner under ét, kan man umiddelbart konstatere, at både de programpolitiske målsætninger og de overordnede strategier, der arbejdes efter, er temmelig ens. Målet er på den ene side at bevare en dominerende eller i det mindste stærk markedsposition, så man kan sikre høj dækningsgrad, og på den anden side at fastholde et bredt, alsidigt programudbud, dvs. drive såkaldte fuldskalakanaler, hvor alle programtyper er repræsenteret. På det strategiske plan er der enighed om, at opgaven består $\mathrm{i}$ at finde balancen mellem konkurrence om seerandele og programmæssig komplementaritet, idet man altså på én gang vil konkurrere med kommercielt tv og tilbyde publi- kum substantielle alternativer til det kommercielle programudbud. Det er en fælles erkendelse, at skal disse mål indfris, stiller det store krav til programlægningen, og både DR, NRK og SVT lægger i deres strategiplaner afgørende vægt på dels at udvikle og forbedre programlægningen, så de enkelte programmer får bedst mulig placering, og dels på gennem programfladens opbygning og æstetiske form at skabe en mere markant kanalidentitet. Den fælles udfordring består i at »sælge" programudbudet bedre gennem en mere offensiv og seervendt programlægning i en situation, hvor det økonomiske spillerum for strategiske satsninger og nye initiativer bliver stadig mindre. De økonomiske begrænsninger gør selvsagt ikke opgaven med at strategisk programfladestyring lettere, da ressourcerne nødvendigvis må hentes andre steder i institutionernes budgetter, men interessant nok har den betrængte ressourcesituation været med til at gennemtvinge rationaliseringer og organisatoriske omlægninger, som næppe ellers havde været mulige at gennemføre. Et andet forhold, som har accentueret behovet for programfladestyring, er problemerne med at operere et to-kanalsystem på en hensigtsmæssig måde, som forener hensynet til public serviceforpligtelserne med strategiske målsætninger. For DR og NRK's vedkommende har opbygningen af en ekstra kanal (i begge tilfælde skete det i 1996) fundet sted som led i bestræbelserne på at styrke den markedsmæssige stilling og løse nogle af de programpolitiske problemer, som er forbundet med at være monokanaloperatør, mens SVT, som siden 1969 har haft to kanaler, af ressource- og konkurrencemæssige årsager har forsøgt at omstrukturere og profilere sine kanaler på en ny måde. Intet tyder dog på, at reorganiseringen af to gamle kanaler er nogen lettere opgave end at etablere en ny supplerende kanal, og grundlæggende er de profileringsspørgsmål, man står over for, de samme (Edin 1998 og 2001). Sammenligner man SVT's aktuelle problemer med de vanskeligheder, der har mødt DR og NRK, ser det tvært imod ud til, at hvor de sidste i forskelligt omfang trods alt har kunnet drage organisatoriske og markedsmæssige fordele af at introducere nye kanaler, har SVT indtil videre ikke fået meget andet end nye problemer ud af sine forsøg på at reorganisere og (ny)profilere sine kanaler.

På baggrund af de analyser, vi har udført, er DR den institution, der indtil videre har den 
mest udviklede programfladestyring, efterfulgt af NRK, mens SVT til gengæld ikke er kommet særlig langt i denne proces. Samtidig kan vi finde belæg for den tese, at det, der tilsyneladende har været afgørende for gennemførelse af en stærk programfladestyring, er omfanget af de markedsmæssige og økonomiske problemer, som institutionerne har været udsat for. Der er ingen tvivl om, at DR har været hårdest ramt af seermæssig tilbagegang, og at det også er den institution, der har haft mest brug for at løse sine økonomiske problemer. NRK's problemer med seertilslutning har været noget mindre, men de har alligevel været voksende, og i sammenhæng med stigende økonomiske vanskeligheder har NRK med nogen forsinkelse fulgt i DR's fodspor. Det er endnu for tidligt at sige, om SVT vil gøre det samme, men på en række områder er der træk, der peger i denne retning, skønt der også kan findes modsatrettede træk, hvilket blot vidner om de alvorlige interne konflikter i SVT.

\section{Faser i udviklingen af programfladestyring}

Der er næppe kun én opskrift på, hvordan programfladestyring kan gennemføres, og ser man på udviklingen i DR, NRK og SVT, står det klart, at mange forskellige både formelle og uformelle forhold spiller ind på en måde, som gør det svært at generalisere. Ikke desto mindre har alle tre institutioner i løbet af 1990'erne gennemført reformer, som har til formål at styrke programfladestyring og i det hele taget at give programfladen en mere fremtrædende plads i organisationen. Der er alle steder tale om en gradvis udvikling, der i de tre institutioner, vi behandler her, forløber gennem flere forskellige faser.

Da udviklingen af programfladestyring imidlertid finder sted sideløbende med andre reformer, som griber ind i og påvirker den del, som har med programfladestyringen at gøre, kan det under tiden være vanskeligt at gennemskue, hvad der er virkning og hvad der er årsag. I SVT har processen mod en stærkere programfladestyring været påvirket af en række reformer af hele kanalstrukturen, som i nogen grad har bremset og i hvert fald kompliceret udviklingen. I DR og NRK har etableringen af en formaliseret programfladestyring fundet sted parallelt med gennemgribende rationaliseringer af produktionssiden, idet man begge steder har indført intern fakturering i produktionen, dvs. et system, hvor ressourcestyringen foregår efter faste priser på de enkelte programmer $o g$ de faciliteter og services, der medgår til dem. Dette system udgør, som NRK's økonomidirektør påpeger, en helt elementær forudsætning for overhovedet at kunne foretage målrettet ressourcestyring: »Å styre forbruket av noe som er 'gratis' er bortimod umulig« (cit.f. Ytreberg 2001: 18). Den interne fakturering bidrager samtidig til at synliggøre, hvad forskellige programtyper koster, og lægger dermed op til en langt mere »omkostningsbevidst « ressourcestyring end før. Såvel i DR som i NRK og SVT var der som nævnt et voksende behov for at bringe omkostningerne ned, ikke mindst for at frigøre midler til udvidelse af sendetiden, og til det formål er systemet med interne fakturering blevet udbygget ved at etablere et egentligt marked for de programproducerende afdelingers køb af faciliteter og services enten internt $i$ institutionen eller hos eksterne leverandører. Det er dette system, som i BBC går under betegnelsen "producer's choice « ${ }^{4}$, og som indebærer, at de økonomiske midler placeres hos programproducenten, som så indkøber de nødvendige services og faciliteter hos den leverandør, der tilbyder den laveste pris (Harris et al. 1998). I DR, hvor "producer's choice« har fungeret i nogle år, har det medfort ganske markante besparelser og har tvunget DR til at producere programmer, der prismæssigt ligger på niveau med konkurrenterne. Organisatorisk indebærer det et kunde-leverandørforhold, hvor programafdelingerne er blevet adskilt fra den del, der har med teknik og faciliteter at gøre, dvs. en opdeling i "produktion« og »faciliteter«, som det kendes fra BBC. I BBC's "producer's choice« er det imidlertid ikke bare programproducenten, der opererer på et marked og frit vælger leverandør. Også udsendelsesvirksomheden (»BBC Broadcast «) blevet organisatorisk adskilt fra produktionssiden (»BBC Production«), og i dette system er det så »broadcasteren«, der frit vælger, hvad der skal produceres, og hvem der skal gøre det, så at altså også relationen mellem »broadcaster« og »produktion « har markedsmæssig karakter.

Det er klart, at også denne side af "producer's choice« rummer store rationaliseringsmuligheder, fordi den konkurrence, der opstår, tvinger producenterne til at holde priserne nede ${ }^{5}$, men, som vi skal se, er det samtidig et ressourcestyringssystem, der tildeler opdragsgiveren eller kunden, om man 
vil, den egentlige magt, og det er derfor ligeså meget et redaktionelt styringsinstrument som en ressourceallokeringsmekanisme. I DR har man i 1997 indført en modificeret udgave af »producer's choice« i forholdet mellem programlæggere og programproducenter netop med henblik på strategisk programfladestyring og programudvikling ${ }^{6}$ og kun sekundært af økonomiske grunde. I NRK var man længe indstillet på at omlægge ressourceforbruget i produktionsdelen gennem "producer's choice« $\mathrm{i}$ forholdet mellem produktion og faciliteter, mens man til gengæld tøvede med at gøre dette princip gældende i relationen mellem udsendelsesvirksomhed og produktion.

Hvis vi nu vender tilbage til de enkelte faser $\mathrm{i}$ den proces, der har fort til etableringen af strategisk programfladestyring i først og fremmest DR og NRK, i mindre grad i SVT, er det karakteristisk, at det første skridt består i, at man institutionaliserer selve programlægningen som et strategisk kærneområde, så man bliver i stand til at organisere den eksisterende programportefølje bedre ud fra overordnede programpolitiske retningslinjer og konkurrencehensyn. Både i DR og i NRK oprettes en egentlig programredaktion med ansvar for programfladens sammensætning, og i SVT bliver den enhed, der stod for programlægningen, styrket gennem sammenlægninger af tidligere adskilte funktioner. I den sammenhæng udvikles gradvist fastere, mere slot-baserede programflader, hvor stadig flere programmer får fast placering, og hvor de forskellige dele af sendefladen opdeles mere systematisk. I første omgang betyder udviklingen af nye, mere professionelle måder at organisere programfladen på imidlertid ikke, at programproduktionen lægges om, og der heller ikke tale om ændringer, som på nogen afgørende måde griber ind $\mathrm{i}$ institutionernes organisation. Den tætte integration af produktions- og udsendelsesvirksomhed, som opstod i monopoltiden, opretholdes, blot bliver udsendelsesvirksomheden nu tillagt større betydning, end det tidligere var tilfældet, $\mathrm{og}$ får tildelt flere ressourcer i form af en bedre og mere professionel bemanding. I hovedsagen er der nemlig blot tale om, at man organiserer de enkelte programmer bedre og efter andre og mere konkurrenceorienterede principper end tidligere.

Det næste, vigtige skridt består i, at udsendelsesvirksomheden bliver gjort til et ledelsesmæssigt kærneområde, primært fordi det er på dette område, at det er muligt at føre den form for offensiv strategisk styring, som den voksende konkurrence nødvendiggør. Denne ændring indebærer ikke nødvendigvis, at ledelsesstrukturerne laves om, men hviler ligeså meget på, at den øverste ledelse i stigende omfang begynder at forholde sig mere direkte til programvirksomheden, altså til »produktet«, hvor den tidligere havde koncentreret sig om selve organisationen. Den nye, ledelsesmæssige interesse for programsiden beror i et vist omfang på ansættelse af nye ledere med andre kvalifikationer end de gamle (større reformer opstår typisk ved lederskift), men må også ses som led i den gradvise omdannelse af public service-institutionerne fra forvaltningsorganisationer (etatsorganisation) til koncerner, der driver medievirksomhed, altså en udvikling, som sat på spidsen betegner overgangen fra offentlig kulturinstitution til kulturindustri (Lowe et al. 1997). Den voksende fokusering på udsendelsesvirksomheden som hovedområdet for strategisk ledelse betyder ikke blot, at ledelsen nu i stigende grad opnår direkte indflydelse på programfladens sammensætning, men også, at den måde, hvorpå ressourcerne fordeles internt $\mathrm{i}$ institutionerne, kommer under pres. Det er nemlig vanskeligt at gennemføre en programrettet, strategisk ledelse $\mathrm{i}$ institutioner, hvor produktions- og udsendelsesvirksomheden er ressourcemæssigt og organisatorisk integrerede, og hvor produktionssiden tilmed udgør det organisatoriske tyngdepunkt og lægger beslag på stort set alle de økonomiske ressourcer. Hertil kommer, at driften af to, indbyrdes forskelligt profilerede kanaler, som gensigt skal supplere, men helst ikke konkurrere med hinanden, skaber behov for en betydelig koordination, som ikke hensigtsmæssigt kan udgå fra produktionssiden, hvad SVT's erfaringer og i nogen grad også erfaringerne fra det første år med NRKTO viser. Det gælder så meget mere, som kanalprofileringen i høj grad er konceptbaseret snarere end programfunderet, dvs. skabt gennem overordnede værdiforestillinger, som manifesteres i kanalernes stil og henvendelsesform, som det i dag er tilfældet i både DR, NRK og SVT

Den tredje fase i processen indebærer ganske omfattende organisatoriske ændringer, hvor produktionssystemet indrettes, så at det understøtter en overordnet, central programfladestyring efter de principper, der indgår i BBC's "producer's choice«. Det drejer sig på den ene side om en både organisatorisk og budgetmæssig adskillelse af programproduktionen og udsendelsesvirksomhed og 
på den anden side om indførelse af et programbestillings- eller kommissioneringssystem, hvor de, der har ansvar for programfladens opbygning, frit kan vælge ikke blot, hvilke programmer der skal produceres, men også hvem der skal producere dem. Kun i DR er et sådant system blevet fuldt gennemført, mens noget tilsvarende først er blevet indført i NRK i forbindelse med oprettelsen af NRK Kringkaster. SVT har derimod ikke omlagt sin organisation i samme omfang, men har forsøgt at indarbejde et programbestillingssystem inden for de eksisterende strukturer.

Den adskillelse af udsendelsesvirksomhed og produktion, som er gennemført i DR og nu også i NRK, udgør organisationsmæssigt nok det mest radikale skridt ${ }^{8}$, men har i sig selv ikke andet formål end at sikre, at de programfladeansvarlige kan træffe redaktionelle valg uafhængigt af produktionsrelaterede forhold. Ikke desto mindre indebærer det en institutionalisering af projektstyret ressourceallokering, idet alle budgetter gøres direkte programrelaterede. Systemet bygger nemlig på, at programlæggerne køber programmer i de forskellige programafdelinger, hvis ressourcer dermed gøres afhængige af, i hvilket omfang de er i stand til at få programforslag antaget. Sigtet med disse organisatoriske og budgetmæssige omlægninger er for det første at opnå en central styring af produktionen ud fra hensynet til programfladens sammensætning og for det andet at stimulere til effektivitet og kvalitet ved at skabe konkurrence mellem programafdelingerneindbyrdes og mellem dem og eksterne producenter. Som Tom Coldbjørnsen formulerer det i en rapport til NRK's ledelse, drejer det sig om »en organisasjonsform som konfronterer flest mulig avdelinger med konsekvensene av "publikums dom « (Coldbjørnsen 1997: 4). Hertil kommer for det tredje, at ressourcestyring og programstrategi kobles direkte sammen, hvilket først og fremmest skaber større fleksibilitet, end det var muligt i det gamle system, hvor programafdelingerne havde faste budgetter, og sikrer, at overordnede programstrategiske beslutninger bliver fort ud i livet.

\section{Modeller for programfladestyring}

De tre faser i udviklingen af programfladestyring, som vi har identificeret, indebærer voksende centralisering, hvor den øverste ledelse har fået udvidet sin magt over den samlede programvirksomhed, mens de programproducerende enheder til gengæld har mistet indflydelse, ikke blot hvad angår enkelte produktioner, men også med hensyn til programfladernes udformning. Vi skal senere vende tilbage til de interne konflikter, som disse forskydninger har givet anledning til, men vil her koncentrere os om ganske kort at pege på nogle mere principielle forhold vedrørende programfladestyring. Når man ser på, hvordan programfladestyring kan gribes an, vil det være muligt at definere i det mindste tre, måske endda fire forskellige modeller, som alle refererer til magt- og kompetenceforholdet mellem på den ene side dem, der producerer programmer, og på den anden side dem, der har ansvar for udsendelsesvirksomheden, hvorunder sammensætningen af programfladen hører. Det drejer sig som nævnt om to sider af programvirksomheden, som i de gamle public service-institutioner har været tæt integrerede, og som ført nu er ved at blive skilt ad. I DR, NRK og SVT har produktionssiden været ganske omfattende divisioneret i en række selvstændige programafdelinger, typisk opdelt efter programområder og faglige kompetencer (nyheder, sport, kultur, underholdning etc.), mens de funktioner, der knytter sig til udsendelsesvirksomheden, generelt har været temmelig begrænsede både med hensyn til ressourcer og indflydelse og hovedsagelig har haft logistisk karakter.

Blandt mulige modeller for programfladestyring har vi i den ene ende det, som Ellis omtaler som en »tilbudsstyret« model (Fig. I), hvor det altså er programproducenterne, der tilbyder programmer eller programideer, som programlæggerne så kan vælge mellem. Det er denne form, der ideelt set har været praktiseret i public service-institutionerne i monopoltiden, og som har betydet, at produktionsdelen her har udgjort det institutionelle kærneområde, $\mathrm{og}$ at de producerende medarbejdere har haft ganske betydelig indflydelse. I den henseende er der tale om en model, som understøtter kreativitet, hvis man derved forstår tilstedeværelsen af størst mulig frihed, og som derfor passer godt ind i billedet af public service-medierne som kulturinstitutioner. Williams' forestilling om, at den eneste måde at opnå sand "public service« på, består i »at skabe en ny slags institutioner«, hvor »de aktive kulturarbejdere kontrollerede deres egne udtryksmidler« (Williams 1963: 116), var på sin vis en realitet i Norden i 1960'erne og 1970'erne. 
Fig. I: Tilbudsstyring

Produktion

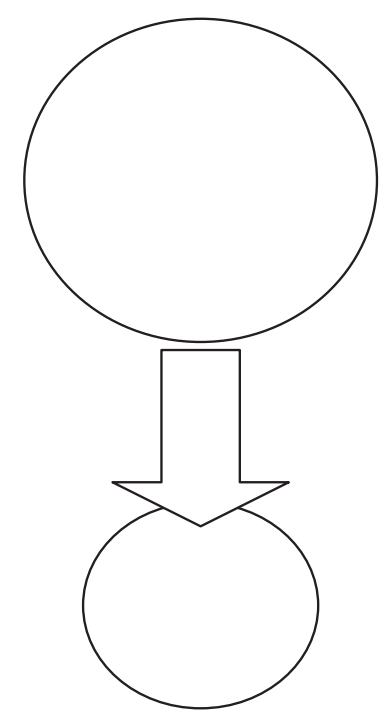

Programlægning

Fig. III: Dialogstyring

Produktion

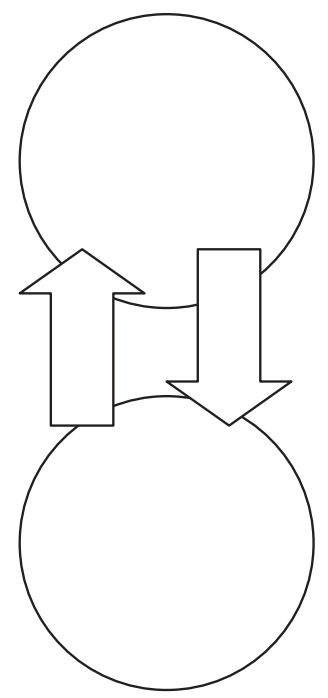

Programlægning
Fig. II: Eftersporgselsstyring

Produktion

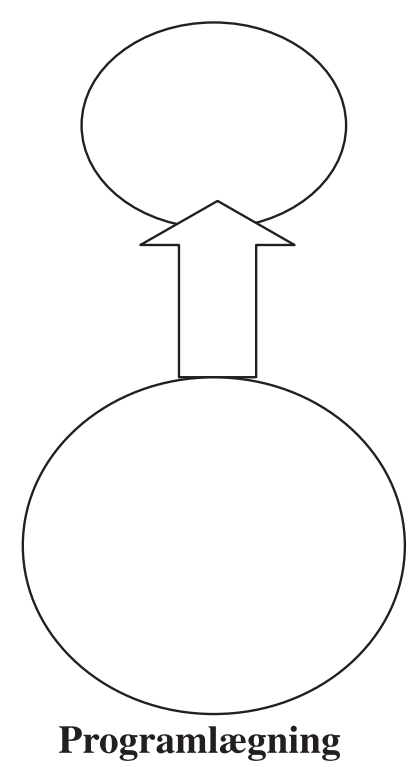

Fig. IV: Organisationsstyring

Produktion

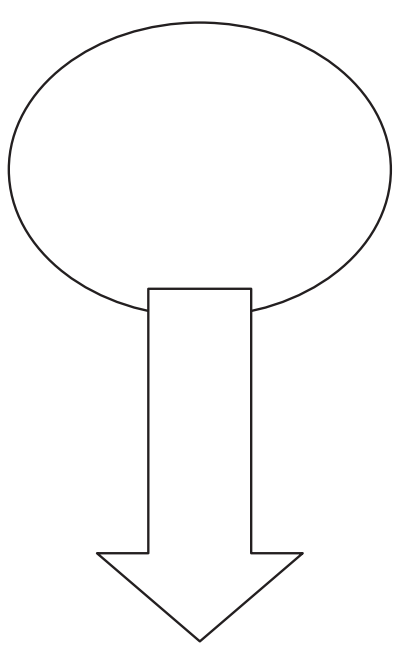

Programlægning 
I den anden ende har vi det, som vi med Ellis kan kalde en »bestillingsstyret« model (Fig. II), hvor det omvendt er programlæggerne, der bestiller de programmer, som de ønsker skal indgå i sendefladen, og hvor produktionssiden har leverandørstatus. Denne model genfindes i BBC's "producer's choice«, men ellers er mest udbredt i kommercielt tv, som kommissionerer programmer hos uafhængige producenter. Det siger sig selv, at programmedarbejderne - de aktive kulturarbejdere, om man vil - ikke har samme frihed som i »tilbudsmodellen«, og sat på spidsen kan man sige, at det her drejer sig om en model, der passer bedre til billedet af fjernsyn som kulturindustri end som kulturinstitution. Der er imidlertid ikke uden videre tale om, at kunstnerisk kreativitet er afløst af marketing, som kritikere af »producer's choice« ofte hævder, men nok så meget om, at kreativiteten ikke længere entydigt er lokaliseret i produktionsmiljøerne, men nu også omfatter programlæggerne og deres redaktionelle stab.

Mellem disse to modeller findes der, hvad vi bedst kan betegne som en »dialogstyret« model (Fig. III) (Ytreberg 2001), som bygger på dialog og forhandlinger mellem producerende enheder og den programfladeansvarlige redaktion, og hvor der altså er tale om et samspil, en udveksling, mellem disse instanser. Dialogmodellen kan måske bedst betragtes som en overgangsløsning, som et mellemtrin i ændringen fra »tilbudsstyring" til »bestillingsstyring«, og den har tidligere været praktiseret i både DR og NRK, mens den stadig findes i SVT. Som vi skal se, hviler den form for "producer's choice«, som er indført i DR, dog i nogen grad på dialogmodellen, for så vidt angår kommissioneringsprocessen, mens den organisatorisk ikke gør det, fordi programafdelingerne ingen formel indflydelse har på programfladen. Skønt »dialogmodellen« kan betragtes som en pragmatisk, kompromisorienteret løsning, er det værd at understrege, at den også implicerer et møde mellem forskellige kreative instanser, og at den ikke nødvendigvis bare fører til kompromiser, men ligeså vel kan bidrage til kvalitativ udvikling.

I de tre idealmodeller, vi her har skitseret, er styringen af programudbudet placeret hos enten producenterne, hos programlæggerne eller er delt mellem dem. Der findes imidlertid endnu en styringsmodel, som adskiller sig fra de øvrige ved ikke at indeholde noget skel mellem produktionsdelen og udsendelsessiden. Af grunde, som straks vil fremgå, kan vi kalde den for den »organisationsstyreder model (Fig. IV), og den er interessant i denne sammenhæng, fordi den bedre end nogle af de andre modeller beskriver de faktiske forhold i de nordiske public service-institutioner ikke blot i monopoltidens sidste år, men også i konkurrencens første fase. I virkeligheden kan den måske knapt nok siges udgøre en programfladestyringsmodel, fordi den i sin virkning netop udmærker sig ved, at programfladen opstår relativt ustyret som et spejlbillede af den måde, hvorpå programproduktionen er organiseret og af den interne ressourcefordeling. Magten over programfladens sammensætning ligger i de programproducerende afdelinger, som hver leverer en vis mængde programmer til sendefladen, men hvis bidrag til denne i det væsentlige er bestemt af afdelingerne selv på baggrund af faste årlige budgetter. Beslutningen om, hvor i sendefladen de enkelte afdelingers programmer skal placeres, er overladt til et kollegialt organ, hvor de enkelte programafdelingers chefer indbyrdes forhandler om de bedste placeringer i sendefladen.

I DR, NRK og SVT indebar dette system, at programlæggerne af programafdelingerne fik tilbud, som de ikke kunne takke nej til, ganske enkelt fordi programafdelingerne selv besluttede, hvad de ville producere, og fordi der ikke var råd til at afvise programmer, som allerede var produceret eller sat i produktion. For programlæggerne har det derfor været et fait et compli, hvor opgaven har bestået $\mathrm{i}$ at få det bedste ud af de forhåndenværende programmer. Derfor kan man med en vis ret sige, at den reelt praktiserede programfladestyring var et »bestillingssystem«, hvor programproducenterne bestilte plads i sendefladen til de programmer, som de selv ønskede at producere.

I programpolitisk henseende har dette system ganske vist skabt en høj grad af alsidighed, for så vidt som programafdelingerne hver især har produceret noget forskelligt, og man kan sige, at det er et system, som i en vis forstand overflødiggør en samlet programpolitik (politikken ligger nemlig implicit i organisationsstrukturen). Til gengæld er der tale om et system, hvor hensynet til programfladens samlede arkitektur og dermed hensynet til seerne træder i anden række, og af samme grund vil det nærmest være umuligt at foretage nogen form for strategisk planlægning. Den »organisationsstyrede« model har nok de bedste betingelser 
for at fungere, når der kun skal drives én tv-kanal, som det var tilfældet i DR og NRK før 1996, fordi man så undgår de koordinationsproblemer, som et to-kanalsystem indebærer. Ikke desto mindre kan man sagtens drive to kanaler med hver sin profil ud fra et lignende princip, når blot hver kanal får sin egen specifikke organisation, som så skaber en bestemt profil. Det er præcis en sådan tanke, der har ligget bag SVT's tidligere opdeling i en Stockholmskanal (Kanal 1) og en distriktskanal (TV2) baseret mere eller mindre på hver sit produktionssystem og med til dels separate organisationer. Når denne styringsform har domineret i de nordiske public service-institutioner, har det formentlig baggrund i en stærk tradition for kollegiale styreformer og et politisk ønske om at sikre pluralitet og modvirke centralisering i monopolinstitutioner, men det kan også ses som resultatet af, at institutionerne i udpræget grad har været indadvendte og fokuseret mere på de interne relationer end på forholdet til publikum.

Ellis' centrale pointe er, at selve udgangspunktet for programplanlægning har ændret sig som følge af konkurrencen, så at programfladen »drives the planning of output. It used to put programmes in order. Now, in the American phrase, it 'orders programmes' from the producer« (Ellis 2000: 143). Den udvikling, som Ellis identificerer med udgangspunkt i det engelske tv-system, kan dog ikke uden videre overføres til de nordiske public service-institutioner, dels fordi »dialogmodellen« stadig er dominerende, selv i de institutioner, som har indført "producer's choice«-princippet i organisationen, og dels fordi det, der var gængs praksis, for omlægningerne fandt sted, snarere var den »organisationsstyredemodel«end»tilbudsstyringsmodellen « ${ }^{9}$. Ellis’ modstilling mellem »offer lead « og »demand lead« programstyring må derfor siges at være noget forenklet, ikke mindst når der anlægges et magtpolitisk perspektiv på udviklingen. I det gamle system havde programskaberne i følge Ellis en nøglerolle, mens det i dag »the senior management, « som indtager denne position. Det er imidlertid vigtigt at hæfte sig ved, at det ikke blot drejer sig om en forskydning fra »idéskabere« til »administratorer«, men nok så meget om, at styringen har fået et andet udgangspunkt. Det centrale i overgangen fra »offer lead« til »demand lead« styring er først og fremmest, at et system, hvor de enkelte programmer styrer programfladens sammensætning, afløses af et system, hvor program- fladen styrer, hvilke programmer der produceres. Når Ellis omtaler det sidste som et »demand lead system«, er det ikke primært, fordi ledelsen efterspørger og bestiller bestemte programmer, men snarere fordi programfladen så at sige genererer en bestemt efterspørgsel. Det interessante er derfor heller ikke så meget, om programskaberne eller ledelsen har magten over fjernsynet, som om hensynet til enkeltprogrammer eller hensynet til den samlede sendeflade udgør det overordnede styringsprincip. Magtforskydningen mellem producenter og ledelse er i virkeligheden ikke andet end en afledt effekt af, at hensynet til programfladen kommer i centrum.

\section{Kommissioneringscirklen}

Den måde, hvorpå programlæggerne og dem, der har ansvaret for programfladens opbygning, bestiller programmer hos producenterne, interne såvel som eksterne, har selvsagt ganske stor betydning for, hvilket programudbud seerne præsenteres for, og er samtidig afgørende for, hvilke relationer der skabes mellem programlægningen og programafdelingerne. Det sidste er ikke blot vigtigt, når man vil forstå karakteren af de institutionsinterne konflikter, som programfladestyringens udbredelse har skabt, men også væsentligt for at kunne belyse programfladestyringens konsekvenser for public service-mediernes programpolitiske udvikling.

Både DR og NRK, i mindre grad også SVT, har indført faste, formaliserede procedurer for programplanlægning, som baseret på en årlig cyklus sigter mod at »omsætte« overordnede programstrategiske ideer i konkret programvirksomhed under hensyntagen til de økonomiske ressourcer, der disponeres over. En sådan planlægning har altid fundet sted, men tidligere bestod den primært $\mathrm{i}$ at fordele ressourcerne mellem de forskellige afdelinger, som så ud fra de tildelte budgetter producerede programmer inden for hvert sit fagområde. Når først pengene var fordelt, blev den egentlige programplanlægning overladt til de enkelte afdelinger, som i det væsentlige disponerede ud fra egne behov og interesser. Da dialogen mellem afdelingerne var begrænset, og da der ikke fra institutionsledelsens side blev foretaget nogen systematisk koordination, var det programmæssige produkt, der kom ud af denne planlægningsform, temmelig uforudsigeligt. Af- 
gørelsen af, hvilke programmer der skulle sættes i produktion, fulgte ikke formaliserede procedurer, men var i hovedsagen overladt til de enkelte programafdelingschefer, hvilket ikke blot gjorde beslutningsprocessen uigennemskuelig og må have givet plads for en høj grad af vilkårlighed, men også betød, at de enkelte afdelinger reelt kunne følge hver sin programpolitiske målsætning.

Med omlægningen til central programfladestyring blev udgangspunktet for planlægningen flyttet fra budgetterne til sendeplanen, tydeligst i DR, hvor sendeplanen reelt afgør de enkelte programafdelingers budgetter, i lidt mindre grad i NRK og mindst konsekvent i SVT, hvor programafdelingerne fortsat har faste budgetter. Både i DR og NRK, men til dels også i SVT, er den centrale styringsmatrix i dag den såkaldte modelslotplan (DR) eller typeuke/typvecka (NRK/SVT), hvor de enkelte slots i sendefladen er præcist defineret med hensyn til stofområde, format, intenderet målgruppe, estimeret seertal og produktionspris. Modelslotplanens udformning er i DR og NRK blevet til efter et indledende strategiseminar, hvor de overordne målsætninger, nye initiativer og ændrede prioriteringer fremlægges og diskuteres af chefredaktionen, tv-direktøren og programafdelingslederne. På baggrund af de strategiske beslutninger, der træffes vedrørende programpolitikken, og på grundlag af erfaringerne med det foregående års sendeflade udarbejder i DR chefredaktionen, i NRK programredaktionen modelslotplanen/typeuken - i SVT er det planlægningschefen, der har denne opgave.

Selve arbejdet med modelslotplanen er ret afgørende for det videre forløb, fordi det fastlægger rammerne for den efterfølgende proces. I DR og NRK arbejdes eksplicit med en række kvantitative målsætninger i form af forventet »share« (både generelt og i målgrupper) og kvalitetsvurdering, fordeling af programtyper (genrer), mål for national produktion og økonomi, så man kan være nogenlunde sikre på, at modelslotplanen kan finansieres, giver det intenderede seertal og opfylder de programpolitiske fordringer. I DR, hvor den strategiske konkurrencetænkning har manifesteret sig tydeligst, er hovedprincippet, at de dele af programfladen, som har indfriet de på forhånd formulerede forventninger, bliver videreført, mens der derimod foretages justeringer på områder, hvor det ikke er tilfældet. Det betyder ikke, at der kun anlægges markedsstrategiske hen- syn, som man måske kunne tro, men derimod at de enkelte slots vurderes ud fra, om de har opfyldt på forhånd definerede målsætninger. I øvrigt kan programmer, som seertalsmæssigt har klaret sig dårligt, godt blive videreført, hvis de vurderes at være tilpas vigtige. I fastlæggelsen af modelslotplanerne for begge DR's kanaler indgår også de overordnede principper for kanalprofilering, der anvendes som en slags redaktionelle retningslinjer. I NRK, som i højere grad end DR har givet de programproducerende afdelinger indflydelse på sendeplanarbejdet, er opbygningen af typeugen et forhandlingsspørgsmål mellem fjernsynsdirektøren, programredaktionen og cheferne for programafdelingerne, hvor der forsøges opnået en balance mellem afdelingernes interesser og de overordnede strategiske hensyn. Udarbejdelsen af SVT's typeuge blev i den periode, vi her beskæftiger os med, i første omgang varetaget af planlægningschefen, som i en senere fase justerede den efter samråd med syv såkaldt »genreansvarlige« og efter diskussioner i programledelsen. Ligesom i NRK opstår typeugen gennem dialog og forhandling mellem de involverede parter, om end de programproducerende afdelinger i SVT blev inddraget på mere indirekte vis gennem de genreansvarlige. De genreansvarlige var dog ikke uden videre programafdelingernes repræsentanter, men indtog en dobbeltrolle, fordi de både var medlemmer af programledelsen og ansatte $i$ programafdelingerne ${ }^{10}$.

Den proces, der skal omsætte modelslotplanen i programmer, er udformet temmelig forskelligt i de tre institutioner, men fælles for dem er, at der med udgangspunkt i modelslotplanen udarbejdes detaljerede planer for, hvilke programmer der skal produceres, og hvor i sendefladen de skal placeres. I NRK bliver dette besluttet i forbindelse med fastlæggelsen af typeugen, og i den periode, der her behandles, afspejlede de konkrete beslutninger i høj grad fjernsynsdirektørens centrale rolle som den, der afbalancerer hensynet til programafdelingerne overfor de overordnede strategiske hensyn. Fjernsynsdirektøren kommer nok med ideer og ønsker, som er begrundet i hensynet til programfladen, men i beslutningerne vejer produktionsafdelingerne tungt, og det er også dem, der i langt overvejende grad fremkommer med ideer og indspil. I SVT bliver en mindre del af de slots, der er defineret i typeugen, gjort til genstand for en formaliseret »pitching«, hvor 
programafdelingerne bliver bedt om at udarbejde programforslag efter retningslinjer, som er fastlagt af programledelsen. Langt de fleste programmer bliver imidlertid fastlagt ved, at de genreansvarlige foretager en programbestilling på baggrund af forudgående drøftelser med de implicerede programafdelingschefer. I DR er proceduren væsentlig mere formaliseret, idet chefredaktionen på baggrund af modelslotplanen udarbejder rammekoncepter, som er korte beskrivelser af de enkelte slots i modelslotplanen med angivelse af de rammer, der på forhånd er sat for de pågældende slots på baggrund af modelplanen/typeugen (genre, indhold, timepris, målgruppe, seertalsmål). Rammekoncepterne sendes derefter ud i programafdelingerne (i et vist omfang også til eksterne producenter), som efterfølgende fremsender ideer og forslag til programmer. Rammekoncepterne er i DR opdelt i to typer, nemlig i faste slots, som er programmer, der blot skal videreføres og produceres af en bestemt afdeling, og konkurrenceslots, som er programmer, der udbydes i enten intern, ekstern eller i helt åben licitation. De forslag, der efterfølgende kommer ind, bliver så vurderet af den programredaktionelle instans, som foretager udvælgelsen. Den endelige afgørelse af, hvilke programmer der skal produceres, træffes først efter nærmere forhandlinger mellem chefredaktionen og de enkelte afdelinger om pris, indhold $\mathrm{og}$ forskellige formelementer. Når der så er indgået kontrakter mellem chefredaktionen og programafdelingerne om, hvad der skal produceres, udarbejdes den endelige slotplan.

I modsætning til både NRK og SVT opererer DR altså med et formaliseret kommissioneringsystem, som bygger på (hovedsagelig) intern konkurrence, og hvor chefredaktionen har den fulde kompetence til at beslutte, hvad der skal produceres. Imidlertid er det kun en relativt lille del af programfladen, som gøres til genstand for licitation efter de principper, der her er beskrevet. I 2000 var det således kun 15\% af samtlige slots, og kun en tredjedel af dem har været eksterne konkurrenceslots, hvor eksterne producenter har kunnet byde ind. Størstedelen af sendefladen er altså baseret på faste slots, hvor bestemte programafdelinger leverer et på forhånd aftalt antal programmer, og i mange tilfælde er der tilmed indgået flerårige aftaler mellem chefredaktionen og programafdelingerne. Ikke desto mindre er også de faste slot underlagt chefredaktionen, da det er den, der afgør, hvilke slots der skal være faste, og da den også løbende indgår i en dialog med programafdelingerne om justeringer i programmerne.

\section{Redaktionel styring}

I DR er magten over programfladen helt entydigt placeret i chefredaktionen, hvilket først og fremmest betyder, at redaktionelle beslutninger kan træffes (mere) uafhængigt af interne institutionelle hensyn ${ }^{11}$, end det hidtil har været tilfældet i NRK og SVT. En programchef i DR forklarer fordele ved, at det sætter hensynet til seerne i centrum: »Fordelene er fra seernes synspunkt, at man på denne måde sikrer, at man får en masse ideer bragt frem, at man sikrer, at der ikke ude i programafdelingerne er et filter, der sagt lige ud tager andre hensyn end hensynet til, hvad der er et godt program. Nu vælger vi (chefredaktionen), hvad vi synes, DR skal stå for (..) Jeg tror, at et system, hvor dette valg træffes uafhængigt af ressourcer og personalehensyn, er et bedre valg for seerne, end hvis alle de andre parametre skal ind tidligt i processen « (eget interview, 27.6.2000). Som det fremgår, foregår der ikke desto mindre en udstrakt dialog mellem chefredaktionen og de programproducerende afdelinger i løbet planlægningsprocessen, hvilket i praksis betyder, at programafdelingerne trods alt har muligheder for at øve indflydelse både på enkeltprogrammer og på sendefladens opbygning. Nok indebærer licitationssystemet, at chefredaktionen bestiller programmer i programafdelingerne, men i første fase af processen drejer det sig i høj grad om efterspørgsel af programideer ud fra målsætningen om at få så mange ideer på bordet som muligt. Konkurrenceelementet er bevidst indført for at stimulere iderigdom, men også for at give chefredaktionen reelle valgmuligheder, og i den sammenhæng er den formaliserede procedure for "pitching" gennem rammekoncepter, hvori også alle budgetmæssige poster figurerer, en ganske vigtig forudsætning for de prioriteringer, som chefredaktionen efterfølgende foretager. Den mest direkte form for styring ligger i fastlæggelsen af modelslotplanen, fordi det er her den grundlæggende fordeling i programtyper finder sted, men også den konkrete udforming af rammekoncepter indebærer styring, da chefredaktionen her ganske klart signalerer, hvilken slags programideer der efterspørges ${ }^{12}$. 
I DR er programplanlægningen og ansvaret for sendefladens opbygning og profilering entydigt placeret hos chefredaktionen, mens de tilsvarende funktioner er mindre centraliserede i NRK (indtil oprettelsen af NRK Kringkaster) og SVT, hvis programfladestyring af samme grund er væsentlig mere kompliceret og i større omfang end i DR et resultat af interne magtkonstellationer, personlig indflydelse og andre forhold, som ikke eksplicit indgår som præmisser for de programvalg, der i sidste ende foretages. Set i den sammenhæng er en af fordelene ved den programfladestyring, der praktiseres i DR, at den er åben og formaliseret, så alle involverede instanser på forhånd ved, efter hvilke procedurer planlægningen foregår. Dermed har systemet også bidraget til at nedbryde gamle hierarkier og en virksomhedskultur, som i stort omfang byggede på vennetjenester og uformelle kontakter (Flensted-Jensen 2000), og som reelt ofte satte vedtagne programpolitiske beslutninger ud af kraft.

Det siger sig selv, at chefredaktionens opbygning, kompetencer og beføjelser er ret afgørende for, hvilken rolle den kan indtage i programplanlægningsprocessen, og der er næppe tvivl om, at chefredaktionens reelle magt primært skyldes, at den fuldt disponerer over alle programressourcer. I DR er de såkaldte basismidler, som programafdelingerne tilføres, årligt blevet skåret ned, så programafdelingerne dermed er tvunget til at »vinde« slots i licitationsprocessen for overhovedet at få et budget. Som tv-direktøren formulerer det, var det i forbindelse med DR's omstilling fra drifts- til udviklingsorienteret virksomhed »ikke gjort med, at jeg stod op og holdt taler. Så var det nødvendigt at sætte nogle økonomiske mekanismer bag ved (..) Det kunne vi ikke have gjort uden den lidt barske markedsøkonomiske mekanisme« (interview, d. 14.9.2000). Den økonomiske logik, der ligger i »producer's choice«, er derfor ikke blot en ressourcestyringsmekanisme, som indfører almindelige markedsprincipper i institutionen, men udgør ligeså meget et programpolitisk styringsinstrument, hvor man ved hjælp af penge sikrer sig, at det er kunden (in casu chefredaktionen) og ikke leverandøren, der har magten.

Skønt kunde-leverandørrelationen udgør det grundlæggende princip i både program- og ressourcestyringen, betyder det ikke, at programfladestyringen reduceres til en rent økonomisk mekanisme, men blot at den i sin udførelse be- tjener sig af den. De centrale programpolitiske beslutninger, som chefredaktionen har til opgave at implementere, har ganske vist økonomiske konsekvenser for de programproducerende afdelinger, men der er grundlæggende tale om afledte effekter. Den indbyggede »markedsmekanisme« betyder nemlig ikke, som man ellers kunne forledes til at tro, at økonomistyringen afgør, hvilken programpolitik der skal føres. På sin vis var det gamle system, hvor programafdelingerne forvaltede faste budgetter, langt mere økonomistyret, da det var ressourcefordelingen, der reelt afgjorde sendefladens sammensætning.

I DR's programstyringsproces udgør samarbejdet mellem chefredaktionen og de programproducerende afdelinger et af de mest afgørende led, som vanskeligt kan forstås, hvis man alene anskuer det som et kunde-leverandørforhold. I DR er der lagt vægt på at etablere på den ene side en klar afgrænsning mellem chefredaktionen og de programproducerende afdelingers kompetencer og på den anden side at skabe forudsætninger for en løbende dialog mellem disse instanser. Chefredaktionen foretager ganske vist i sidste ende de programbestillinger, der afgør de enkelte programafdelingers produktionsplaner og budgetter, men den spiller samtidig en offensiv rolle i selve idéudviklingen og den løbende evaluering af de programmer, der sendes. I den henseende fungerer chefredaktionen også som en slags konsulenttjeneste, der bistår de producerende enheder med at udvikle og forbedre konkrete programmer ud fra den særlige ekspertise ${ }^{13}$, den besidder (f.eks. vedrørende seertal, seersegmenter, markedsudvikling, betydningen af bestemte formelementer eller trailing), og som programafdelinger sjældent selv råder over. Der er ingen tvivl om, at dette samarbejde mellem chefredaktionen og programafdelingerne i mange henseender bidrager til kvalitetsforbedringer, som næppe ellers ville have fundet sted, og at dette ikke gælder mindre for de enkelte programmer (programserier) end for den samlede programflade. Omvendt er det ligeså klart, at de kvalitetsnormer, der mere eller mindre eksplicit lægges til grund for programudviklingen, tager udgangspunkt i overordnede strategiske hensyn, som sætter hensynet til modtagerne i centrum. I udviklingsarbejdet og i de løbende programevalueringer, der finder sted, spiller ikke mindst forskningsbaseret viden om seeradfærd, herunder også erfaringer indsamlet via prætests, 
en ganske afgørende rolle og bidrager til, at chefredaktionen $\mathrm{i}$ den henseende indgår i processen med en relativt høj faglig profil og derfor også - uafhængigt af dens økonomisk baserede magt - er i stand til at udøve betydelig indflydelse på programudbudet.

\section{Fornyelse eller forarmelse?}

Udviklingen af programfladestyring indebærer, at området for strategisk ledelse får voksende betydning, mens det, der udgør producentlaget i organisationerne, omvendt får indskrænket deres indflydelse. I både DR, NRK og SVT har dette givet anledning til interne magtkampe og konflikter, som i sig selv har indvirkning på institutionernes udvikling, men nok så vigtigt rejser det spørgsmålet om, hvorvidt centraliseret, strategisk programfladestyring udgør en trussel mod public service-mediernes programvirksomhed, måske ligefrem et angreb på selve public service-ideen, eller om det tvært imod bidrager til at styrke (eller i det mindste bevare) public service-medierne.

Da erfaringerne med programfladestyring endnu er få, og DR stadig er den eneste institution, som i flere år har benyttet et formaliseret styringssystem, kan det være vanskeligt at give noget entydigt svar på dette spørgsmål. Set ud fra de nuværende erfaringer afhænger meget dog af, hvordan programfladestyringen konkret gribes an, hvor ikke mindst balancen mellem markedsstrategiske hensyn og hensynet til opretholdelse af tilpas dynamiske produktionsmiljøer spiller en vigtig rolle. Der er ingen tvivl om, at det på mange måder drejer sig om to forskellige, til dels modstridende hensyn, og at det er vanskeligt at finde den optimale balance. Den interne debat i NRK om oprettelse af NRK Kringkaster som led i etableringen af "producer's choice« efter samme model som DR, peger ikke blot på interne interessekonflikter, men også på mere substantielle spørgsmål om, hvordan man bedst organiserer programfladestyring i en public service-institution. De norske erfaringer med at finde en kompromisløsning demonstrerer en slags magtbalance, hvor programredaktionen overvejende repræsenterede markeds-strategiske interesser, mens programafdelingerne og programskaberne omvendt varetog de enkelte programmers interesser, ikke mindst de »smalle« programmer, og i det hele taget var bærere af »ideelle hensyn«, som stod i konflikt med konkurrencetænkningen, men som til gengæld var centrale for public service-ideen (Ytreberg 2001: 66f.). Et af de centrale konfliktområder er i den sammenhæng, i hvilket omfang optimeringen af de enkelte programmers placering i sendefladen går forud for optimeringen af den samlede sendeflade. Som Espen Ytreberg med reference til David Docherty (Docherty 1995) pointerer, »kan nemlig optimalisering av programskjemaet vanskelig sees på som noe mål i seg selv. Det overordnede formålet med denne formen for kringkastning vil nødvendigvis først og fremst knytte seg til selve programmene« (op.cit.: 67). Konflikten mellem markedsstrategiske og programmæssige hensyn har i NRK ganske tydeligt præget programfladestyringen, som i følge Ytreberg har savnet en eksplicit formuleret politik for, hvordan disse hensyn skulle fordeles. Den indbyggede konflikt i programfladestyringen, hvor programmiljøerne inddrages aktivt i processen og indgår i dialog med programlæggerne, blev af fjernsynsdirektøren ikke desto mindre opfattet som en fordel. Fjernsynsdirektøren pointerer således, at interessekampen og debatten har »egenverdi (..), fordi den sikrer de samlet sett bedste beslutningerne« (cit.f. Ytreberg 2001. s. 53). Når han alligevel senere anbefaler, at programafdelingerne fratages ansvaret for programfladestyringen, betegner han det selv som et ideologisk skift: »Jeg støtter det at laga en kringkaster, fordi det betyr at du prinsipielt flytter fokus fra egen organisasjon til publikum« (cit.f. Ytreberg 2110: 21), altså den samme idé, der lå bag DR's indførelse af »producer's choice«.

Også i SVT er denne konflikt mellem de værdier, der udspringer af produktionsmiljøerne, og programledelsens mere markedsorienterede forestillingsverden tydeligt til stede: »Der hade uppstått »två världar«, med strategerna, cheferna och direktörerna i den ena och praktikerna i den andre« (Edin 2001: 37). I SVT har praktikerne imidlertid haft en relativt stærkere position i forhold til strategerne, bl.a. fordi hele ledelsesstrukturen har været uklar og ineffektiv og har resulteret i betydelige ledelsesmæssige konflikter, som har skabt et ganske stort spillerum for programskabernes egne kreativitetsforestillinger og en stærk »institutionsånd«. Chefen for program- og publikumsanalyseenheden, der her repræsenterer de strategiske interesser, påpeger da også dette som et problem: »Det finns mycket spelrum för kreativitet här, planering tillhör inte det mest prioriterade 
- här finns veritabla konstnärssjälar. Allt handlar om programmen. De ses som slutet på historien, men det går inta att fortsätte så, det ër nu det börjar« (cit.f. Edin 2001: 42). Det, der her peges på, er imidlertid ikke så meget den institutionelle fokusering på praktikernes programinteresser, som det er fraværet af en overordnet programfladestyring, der på én gang varetager seernes interesser og forholder sig strategisk til konkurrencen.

I DR, hvor den formaliserede programfladestyring har eksisteret siden 1997, findes lignende konflikter, og også her reflekteres spørgsmålet om, hvordan ideelle hensyn til optimering af enkeltprogrammer kan kombineres med strategiske hensyn til programfladens samlede organisering. Det er dog i mindre grad, end tilfældet er i NRK, et egentligt konfliktområde, hvilket dels skyldes, at programmiljøerne ikke optræder samlet, når programbestillingerne foretages, og dels beror på, at balanceringen af de to slags hensyn allerede er indarbejdet i de modelslotplaner, der ligger til grund for programbestillingen. Det betyder, at chefredaktionen i mindre grad optræder som repræsentant for udelukkende strategiske interesser, men også varetager mange af de »ideelle hensyn«, som i NRK er overladt til programafdelingerne. Programchefen for DR1 forklarer det på denne måde: »Der er ingen tvivl om, at det store er at få programplanen til at fungere, men vi tager også en række andre hensyn« (eget interview, 27.6.2000).

Hvor konflikterne i NRK og SVT markerer sig som en modstilling mellem producenter, der varetager programmernes interesser, og ledelsen, der repræsenterer strategiske interesser, har de en lidt anden form i DR. På den ene side har der været tale om en helt åben og meget voldsom konfrontation mellem ledelsen (herunder chefredaktionen) og medarbejderne, hvor den chefredaktionelle styring og hele programbestillingssystemet af de sidste blev opfattet som direkte undergravende for DR's fortsatte eksistens, og på den anden side har chefredaktionen i praksis fungeret på en måde, som har afbalanceret programhensyn med strategiske sendefladeinteresser. Chefredaktionen indgår nemlig i ganske tæt dialog med programafdelingerne og repræsenterer i den sammenhæng ikke blot formålsrationel management, men bidrager som nævnt også som en slags kreativ »sparringspartner« i programudviklingen og er dermed i realiteten med til at sikre de enkelte produktioners muligheder i sendefladen. Denne funktion beror ikke mindst på chefredaktionens opbygning med et antal redaktører, som varetager bestemte programområder, og som både besidder den programfaglig indsigt, der er nødvendigt for at indgå i de kreative sider af programvirksomheden, og viden om programlægning.

Det er et gennemgående træk i både DR, NRK og SVT, at programfladestyring af en stor del af programskaberne betragtes som $»$ kommercialisering «, i det mindste som en form for formålsrationel markedstænkning, som står i modsætning til en traditionel public service-tankegang, hvor programmerne i sig selv udgør det egentlige mål. I den interne kritik i DR peges der på, at »DR er blevet en centralistisk kommunikations-fabrik i stedet for en mangfoldig kulturinstitution i seernes og lytternes tjeneste« (cit. f. Søndergaard 2001). I DR's tilfælde har programfladestyringen da også baggrund i et målrettet forsøg på at forbedre DR's markedsposition, hvilket åbent indrømmes af tv-direktøren, når han udtaler, at »vi har været seertalsfikserede«. Det er imidlertid værd at notere, at programfladestyring, som den har været praktiseret i DR, nok udgør et effektivt værktøj i hænderne på markedsstrateger, men at det i ligeså høj grad kan fungere »i seernes og lytternes tjeneste«, fordi det muliggør en mere brugervenlig programlægning. En sådan bestræbelse udgør ikke nogen trussel mod public service-principperne, men kan tværtimod betragtes som en fordel, fordi det i sidste ende gør programudbudet mere brugbart for seerne. Den markedsstrategiske betydning af programfladestyring ligger imidlertid ikke blot i organiseringen af programudbudet, så man opnår bestemte markedsandele, men nok så meget $\mathrm{i}$ behovet for profilering af kanalerne gennem målgruppeorientering og opbygningen af en varemærkeidentitet (»branding«). Også denne side af sagen repræsenterer markedstænkning, da det er mediemarkedets udvikling, der skaber dette behov, men omvendt er det en så vigtig forudsætning for overhovedet at få et publikum i tale, at det må betragtes som helt uomgængeligt, og det er samtidig et område, hvor public servicemedierne har reelle muligheder for at bevidst at markedsføre »public service-værdier«. Der er ingen grund til at tro, at den seertalsstyrede brug af programfladerne vil forsvinde, dertil er konkurrencen trods alt for hård, men det er sandsynligt, at programfladestyringen i stigende grad udvikles som et instrument for »branding« og dermed i 
større omfang end i dag også bliver et kreativt udgangspunkt for programvirksomheden ${ }^{14}$.

Ser man på udviklingen i DR's programudbud gennem de senere år, er der ikke belæg for at hævde, at programfladestyringen har ført til, at public service-forpligtelserne er blevet sat over styr, da alsidighedsgraden er blevet opretholdt og tilmed på visse områder yderligere blevet styrket (DR's programregnskab 2001), samtidig med at DR som en af de eneste public service-institutioner har opnået en markant bedre markedsposition, end det var tilfældet, før programfladestyringen blev indført. Det sidste er formentlig en ret afgørende forudsætning for, at programflade-styringen har kunnet opretholdes på trods af betydelig intern modstand. Mange har nemlig i realiteten indset, at det var en uundgåelig udvikling, hvis DR skulle overleve den alvorlige krise, som institutionen befandt sig i i midten af 1990'erne.

Den model for "producer's choice«, som ligger til grund for programfladestyringen i DR, vil utvivlsomt blive fulgt også i NRK og SVT, fordi resultaterne er så overbevisende, og når udviklingen i DR har været hurtigere end i de to andre institutioner, beror det formentlig især på, at DR som nævnt tidligere var under større pres både seertalsmæssigt, økonomisk og med hensyn til politisk legitimitet. Der er ganske vist ingen tvivl om, at programfladestyringen har skabt et »kulturchok« i DR, fordi det har nedbrudt nogle af de gamle magtrelationer, men der har ikke været tale om, at en gammel produktionskultur er blevet afløst af en moderne managementkultur. Sammenlignet med BBC's version af »producer's choice«, der instituerer et indre marked i alle relationer, repræsenterer DR's system en mere "planøkonomisk« og på sin vis også mere åben og dialogorienteret model ${ }^{15}$.

\section{Programfladestyringens grænser}

Trods de oplagte fordele ved programfladestyring er det værd at hæfte sig ved de konflikter og problemer, som dette giver anledning til. Igen er det erfaringerne fra DR, der trækkes frem, fordi systemet her har fungeret tilpas længe til, at nogle af de negative konsekvenser ${ }^{16}$ har vist sig. Det største problem, som systemet skaber, er, at medarbejdernes ansættelsesforhold bliver mere usikre, fordi produktionssystemets størrelse beror på program- afdelingernes evne til at "vinde« licitationerne, hvilket betyder, at en afdeling, som klarer sig dårligt, vil være nødt til at afskedige medarbejdere. Den utryghed, som følger heraf, er næppe i sig selv nogen fordel for kreativiteten, men omvendt er der næppe heller tvivl om, at den også kan stimulere idéudvikling, og det er derfor tvetydigt, hvori dens reelle betydning for kreativiteten ligger. Et andet problematisk forhold er, at programskabernes kreative frihed og autonomi bliver beskåret, fordi de afgørende redaktionelle beslutninger ikke længere træffes i de programproducerende miljøer. For programskabere, der har været vant til at få gennemført egne ideer ${ }^{17}$, kan det naturligvis vanskeligt ses som andet end et tilbageskridt, mens det set fra seernes synspunkt meget vel kan forholde sig modsat. Også her er der tale om en temmelig sammensat problemstilling, som rummer både fordele og ulemper. Hvad der vejer tungest kan ikke uden videre afgøres, da det afhænger af, hvordan den kreative frihed forvaltes af programskaberne. Raymond Williams' diktum om, wat man kan ikke tjene samfundet bedre end ved at give kulturarbejderne deres frihed og de nødvendige midler at arbejde med «(Williams 1963: 117), er ganske vist besnærende, og det finder da også støtte hos nogle af »producer's choice«-systemets skarpeste kritikere, f.eks. Georgina Born, som peger på, at public service-idealerne i BBC i dag alene findes som modstandslommer i produktionsmiljøerne (Born 2000). Omvendt kan man pege på, at producenternes udbredte selvstyre snarere blot har haft til formål at fastholde hævdvundne privilegier og derved reelt har blokeret for nødvendige fornyelser.

Et af de mere håndfaste problemer, som ledsager programstyring, er, at de faglige miljøers integritet bliver anfægtet, hvis hensynet til udsendelsesvirksomheden systematisk fører til nedskæringer i de faglige redaktioner. I BBC har man længe har talt om risikoen for såkaldt »brain drain«, altså en nedbrydning af de produktionsmiljøer, som er forudsætningen for en høj faglig standart. Det er imidlertid især et problem, der opstår i forbindelse med »outsourcing « ${ }^{18}$, hvor brugen af eksterne producenter fører til reduktioner i egenproduktionen, og er derfor ikke i sig selv knyttet til programfladestyringen. Til gengæld kan programfladestyring efter "producer's choice«-modellen føre til så omfattende forskydninger i produktionsmiljøet, at resultatet bliver det 
samme. I DR har man forsøgt at tage højde for dette ved at lade produktionshensyn, dvs. hensynet til de redaktionelle miljøers bærekraft, indgå som et parameter i programbestillingen, og i de sidste par år har man, som nævnt tidligere, tillige forsøgt at tilbageføre redaktionelle kompetencer til programafdelingerne ved at indgå flerårige kontrakter.

Den grundlæggende udvikling, som programfladestyringen understøtter, hvis ikke ligefrem initierer, nemlig bevægelsen fra kulturinstitution til kulturindustri, hvor management spiller en fremtrædende rolle, bryder på afgørende måde med de traditioner og den selvforståelse, der er oparbejdet i de gamle public service-institutioner, og man kan vanskeligt undgå, at nye ledelsesformer påvirker selve virksomhedskulturen, som Küng-Shankleman (2000) overbevisende har vist i en analyse af BBC. I et vist omfang er dette en tilsigtet effekt, fordi det er nødvendigt, hvis institutionerne skal gøres mere »modtagerorienterede«, men det har til gengæld også nogle bivirkninger, som næppe er tilsigtede. Et af problemerne er, at den interne konkurrence, som "producer's choice« aktivt stimulerer, vanskeligt kan undgå at nedbryde noget af den korpsånd, som har præget public serviceinstitutionerne, og at de kollegiale relationer, der var en del af denne, bliver svækkede. Etableringen af et internt marked rummer åbenlyse rationaliseringsgevinster, fordi det påvirker medarbejdernes adfærd, men det skaber også splittelse, som virker undergravende på deres motivation, og som formentlig også gør det vanskeligt at gennemføre den form for værdibaseret ledelse, som institutionerne ellers efterstræber.

$\mathrm{Nu}$ er der ingen grund til at romantisere eksistensen af korpsånd, hvis den reelt ikke består i andet end i forsvaret for et gensidigt privilegiesystem og en fælles modvilje mod ledelsen, men til gengæld bør man nok overveje, hvilken virksomhedskultur der bedst understøtter de strategiske målsætninger, man har sat sig. Det er ikke så meget et spørgsmål om at løfte i flok, som om at vedligeholde faglig ekspertise, der går på tværs af de forskellige programområder, og som strukturelt skaber underlag for forestillingen om public service som et samlet redaktionelt produkt og ikke blot som så og så mange enkeltprogrammer af en bestemt standart. Den måde, hvorpå "public service« i dag defineres, nemlig som primært programpolitiske forpligtelser, som kan måles og vejes i form af et bestemt programudbud (Søndergaard 1999), indebærer en vis demontering af institutionernes betydning som andet end fabrikker, der leverer produkter på bestilling. De kortsigtede fordele, som dette utvivlsomt fører med sig, står dog i et muligt misforhold til de langsigtede risici, man løber, for spørgsmålet er, om ikke public service-mediernes produktionsmiljøer udgør disses »naturgrundlag«, og måske opdager man først, at det er væk, når det allerede er for sent?

Tak til Anna Edin, Teisto Hujanen og Espen Ytreberg for baggrundsmateriale, analyser, diskussioner og kritik, som dette arbejde hoiler på.

\section{Litteratur:}

Andersen, Michael Bruun (1988): »Kan man planlægge kreativitet? Om tv-produktionsanalyse«, MedieKultur, nr. 8.

Bono, Francesco og Ib Bondebjerg (1994) Television in Scandinavia - History, Politics and Aesthetics. Luton

Born, Georgina \& Prosser, Tony (2001): »Culture and Consumerism: Citizenshipm Public Service broadcasting and the BBC's Fair Trading Obligation« (manus).

Coldbjørnsen, Tom (1997): NRKs fremtidige organisajon - Alternative modeller, NRK.

Docherty, David (1995): »Confessions of a Justified Scheduler«, i Andrea Millwood Hargrave: The Scheduling Game, London.

Eastman, Susan Tylor (1997) \& Douglas A. Ferguson: Broadcast/Cable Programming. Strategies and Practices, Belmont

Edin, Anna (2000): Den föreställda publiken, Stockholm.

Edin, Anna (2001): Konsten att producera public service, upubliceret.

Edin, Anna (1998) »Well-ordered competition. The two-channel system in Swedish television«, i Nordicom Review nr. 1/98.

Ellis, John (2000): Seeing things, London.

Flensted-Jensen, Jens (2000): »Flytning med bagtanker«, Samson, nr. 3.

Harris, Martin (1998) og Victoria Wegg-Prosser: »BBC Producer Choice and its outcomes«, i Sue ralph, Jo langham Brown \& Tim Lees (eds.): What Price Creativity?, Luton.

Hellman, Heikki (1998) From Companions to Competitors. The Impact of Competition and Particularly the 1993 Television Reform on Programming Policies and Programme Output in Finland, Tampere.

Jensen, Klaus Bruhn (1993), Kim Schrøder, Henrik Søndergaard, Tine Stampe og Jørgen Topsøe-Jensen: $\mathcal{N} a ̊$ danskerne ser TV. Om danskernes brug og oplevelse af TV som flow, København. 
Küng-Shankleman, Lucy (2000): Inside the BBC and $C \mathcal{N N}$. Managing Media Organisations, London.

Lowe, Gregory Ferrell (1997) og Ari Malm: »Public Service Broadcasting as Cultural Industry«, European Fournal of Communication årg. 12 nr. 2.

McDowell, Walter (1999) og Allen Batten: Branding TV: Principles \& Practices, New York.

Mulgan, Geoff (1993) »Reinventing the BBC«, i Geoff Mulgan og Richard Paterson (eds.): Reinventing the Organisation, London.

Nordicom (1999), Nordic, Baltic Media Statistics 1998, Göteborg.

Paterson, Richard (1993): »New Model BBC«, i Geoff Mulgan og Richard Paterson (eds.): Reinventing the Organisation, London.

Scannell, Paddy (1993): »Time, Place and Space in Broadcasting«, i Kathrine Skretting (red.): Kringkastning og kino, Oslo.

Sepstrup, Preben (1994): Dansk to $i$ kulturpolitsik perspektiv, København.

Starcks, Michael (1993): »BBC Public Service Broadcasting«, i Geoff Mulgan og Richard Paterson (eds.): Reinventing the Organisation, London.

Syvertsen, Trine (1997) Den store TV-krigen. Norsk allmennfjernsyn 1988-96, Bergen.

Søndergaard, Henrik (1994) DR i tv-konkurrencens tidsalder. Frederiksberg: Samfundslitteratur.

Søndergaard, Henrik (1998): »Et spørgsmål om stil«, in Ib Poulsen \& Henrik Søndergaard (red.): Mediebilleder, København.

Søndergaard, Henrik (2001): "Producer's choice» . Programstyring $i$ DR, manus, København.

Søndergaard, Henrik (1999): »Public service ved vejs ende?«, i Ulla Carlssom (red.): Public service tv, Göteborg.

Søndergaard, Henrik (2000): »TV2 som hybridkanal«, i Hanne Bruun, Kirsten Frandsen \& Henrik Søndergaard (red.): TV2 på skermen, København.

Tracey, Michael (1998) The Decline and Fall of Public Service Broadcasting. Oxford.

Williams, Raymond (1963): Massemedierne, København.

Ytreberg, Espen (1998): Allmennkringkasstningens autoritet: Endringer $i$ NRK Fjernsynets tekstproduksjon, 1988-94, Oslo.

Ytreberg, Espen (2001): Programsjemaarbeid i NRK Fjernsynet: Beslutningsprosesser $i$ et maktcentrum, Oslo.

Ytreberg, Espen (2000): »Scheduling in Nordic Public Service Television. General Description of an Ongoing Research Project«, Nordicom Review vol. 21, nr. 1.

\section{Noter}

1 Projektet »Scheduling in Nordic public service television« er finansieret af NOS-S og udført af Anna Edin, Gävle Högskala, Teisto Hujanen, Universitetet i Tampera, Henrik Søndergaard, Københavns Universitet, og Espen Ytreberg, Oslo Universitet.

2 Jf. Hellmann 1999, Syvertsen 1997 og Søndergaard 2000 for beskrivelse af hybridkanalernes rolle.

3 Det er kendetegnende for såvel DR, NRK som SVT, at stigninger i licensindtægterne ikke har kunnet kom- pensere for et voksende udgiftsniveau, som ikke mindst skyldes voksende priser på attraktive programmer og især rettigheder til sportstransmissioner.

4 Betegnelsen »producer's choice« dækker over flere forskellige organisationsprincipper, men betegner først og fremmest en markedsbaseret relation mellem centrale enheder i programvirksomheden: Udsendelse, produktion, faciliteter. Nogle opfatter det overvejende som et økonomisk rationaliseringsprincip (Harris 1998), andre ser det som et ledelsesinstrument (Starks 1993), mens atter andre primært ser det som udtryk for en ny, markedsorienteret virksomhedskultur (Paterson 1993, Born 2000).

5 McKinsey opgør, at "producer's choice« har medført, at BBC på 3 år mellem 1992/93, da systemet blev indført, og 1995/6 har sparet 300 mio. pund, af hvilke 233 mio. pund er blevet reinvesteret i programmer.

6 Programudviklingen var i konkurrencens første faser nærmest gået i stå i DR (Sepstrup 1994), og det udgjorde i følge tv-direktøren et lige så stort problem som den mangelfulde programplanlægning (Søndergaard 2001).

7 Alle steder er derindført en kanalprofilering efter BBC's devise om henholdsvis »our channel « (BBCl) og »my channel« (BBC2), dvs. en bred mainstreamkanal suppleret med en smallere kanal skabt med henblik på et mere selektivt forbrug.

8 Efter at den foreliggende analyse er afsluttet, har DR ændret sin organisation yderlige i den retning, der her er beskrevet, ved at produktionsområdet, der tidligere hørte under tv-direktøren, er blevet udskilt som et selvstændigt område med egen direktør.

9 Forskellen mellem BBC og de nordiske public serviceinstitutioner har på dette område at gøre med, at BBC længe før 1980'ernes »deregulering«havde været udsat for konkurrence fra ITV, og at BBC desuden har været så meget større end de tilsvarende nordiske institutioner, at en styring efter »organisationsprincippet« ganske enkelt ikke har kunnet praktiseres.

10 I sammenhæng med SVT's omorganisering i $2001 \mathrm{blev}$ systemet med genreansvarlige afskaffet bl.a. som følge af de indbyggede loyalitets- og kompetencekonflikter, som dette indebar.

11 Det skal betones, at der i praksis tages ganske vidtrækkende hensyn til de programproducerende afdelinger, idet chefredaktionen forsøger at undgå, at licitationsprocessen fører til alt for store skævvridninger mellem afdelingerne.

12 Et af de meget centrale spørgsmål, som vi ikke kan gå i dybden med her, drejer sig netop om rammekoncepternes detaljeringsgrad. Meget detaljerede rammekoncepter indebærer en mere omfattende styring end åbne koncepter, hvor programafdelingerne indrømmes større frihed, og i praksis har DR i de senere år opereret med en række meget åbne rammekoncepter for at få flere ideer frem på slots, hvor man ikke på forhånd var besluttede på, hvad man ønskede.

13 I DR's chefredaktion indgår institutionens egen kvantitative og kvalitative medieforskning som en vigtig del af de redaktionelle kompetencer.

14 Udviklingen i DR's chefredaktion er et godt eksempel 
på dette. Man har siden 1998 etableret et »kvalitetsprojekt«, som sigter mod at udvikle kvalitetsnormer for forskellige programområder, og som har kvalitetsudvikling som målsætning.

15 Der er flere grunde til dette, men vigtigst er nok, at man ikke i Danmark har haft helt samme ideologiske begejstring for markedsstyring som i England, men også at DR i sammenligning med BBC er en meget lille institution, som derfor kan styres uden at tage de samme »hårdhændede« metoder i brug. Hertil kommer, at BBC også har en langt mere omfattende kommerciel aktivitet end DR, og at dette i høj grad har fungeret som drivkraft til at indføre et indre marked i BBC.

16 Nogle af disse erfaringer har selvsagt indgået i de interne drøftelser og magtkampe i såvel NRK som SVT i forbindelse med planer om indførelse af tilsvarende programfladestyringssystemer, men også de gode er- faringer, hvad angår forbedret markedsposition, har spillet en rolle.

17 Som Jens Flensted-Jensen i en beskrivelse af DR's gamle virksomhedskultur meget rammende påpeger, »opfattede medarbejderen DR som en arbejdsplads, hvor man kunne få nogle personlige og kreative ambitioner tilfredsstillet« (Flensted-Jensen 2001, s. 19).

18 Her skal blot tilføjes, at kravet til DR om at udlægge en del af sin produktion til uafhængige produktionsselskaber med virkning fra 1.1.2003 bliver et lovkrav, og at omfanget af denne »outsourcing« samtidig øges væsentligt, idet det politisk er fastsat til at udgøre $21 \%$ af produktionen.

Henrik Søndergaard er lektor ved Institut for Film- og medievidenskab, Københavns Universitet. 